\title{
Miniatures and Animism: The Communicative Role of Inka Carved Stone Conopa
}

\author{
BILL SILLAR, Institute of Archaeology, University College London, 34 Gordon \\ Square,London,WC1H OPY, UK. Email: b.sillar@ucl.ac.uk
}

\begin{abstract}
Andean offerings use miniaturization and synecdoche to enact connections within a relational animism (where people, places, and things participate in an interactive network), allowing the person preparing the offering to make material links between them and more distant, nonhuman entities. Catholic priests working in the Andes during the Spanish colonial period tried to eradicate these practices in which small objects called conopa were used. Conopa included unmodified stones and carved stone figurines, which were understood to be active agents that helped those who were preparing offerings to communicate with animate locales in the landscape. An analysis of Inka and colonial period stone conopa carved in the form of camelids reveals that some of them were produced in an organized system of manufacture under the auspices of the Inka state. This contributes to a discussion of how Andean household rituals have adapted in response to distinct social, economic, and political contexts.
\end{abstract}

Key words: miniatures, Inka, animism, communication, representation, stone, camelid

This paper focuses on a specific type of miniature made and used by the Inka: small representations of camelids carved in stone, referred to as conopa (Figure 1). Shortly after European colonization, Spanish priests described how native Andean people used these objects in the preparation of offerings, and these colonial descriptions can be compared with aspects of animism in the Peruvian Andes today. The form of these miniatures, the choice of stone, and how they were juxtaposed with other materials and objects in the preparation of offerings suggest that they were understood to create a connection between people, camelid herds, and the animate land. Andean relational animism conceives of the physical world as a multitude of sentient places, objects, and beings that include humans and animals in a community of interdependent entities capable of communication and exchange. Landscape locations such as mountains, lakes, rocks, fields, and houses are named and located as living presences in the world, some of which are associated with the origins of life and are capable of transmitting vitality and substance to other entities (Allen 1988; Bastien

Published online: October 13, 2016

Journal of Anthropological Research (Winter 2016). (C2016 by The University of New Mexico.

All rights reserved. 0091-7710/2016/7204-0004\$10.00 


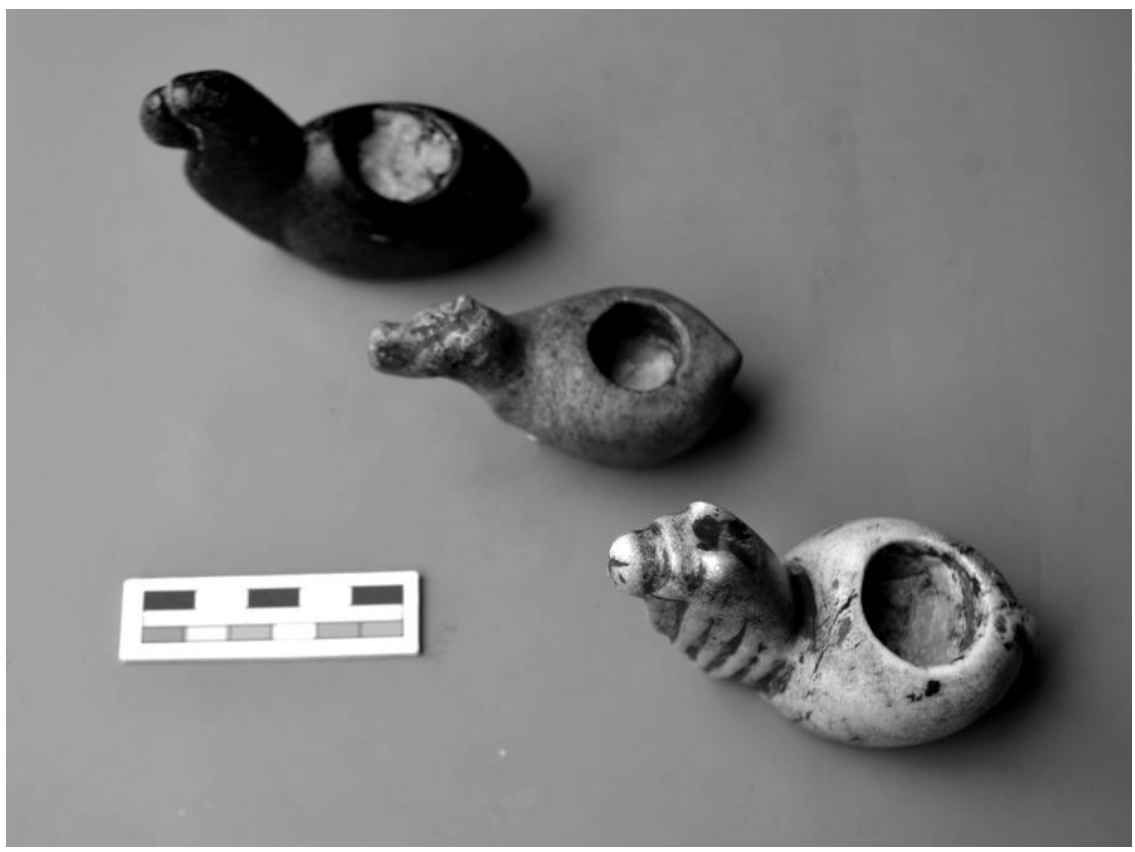

Figure 1. Three conopa with preserved animal fat in the hollowed-out bowls in their backs (Museo de Arqueología y Antropología, Lima, Peru, accession numbers L21369, L21366, L21370).

1978; Gose 1994). Humans are a part of this animate world and have responsibilities to work with the land. By making offerings, people can feed the earth and communicate requests for productivity, health, and well-being. Below I will explain why miniaturization and representation play an essential role within the ritual practice of Andean animism. The preparation of these offerings is a ritual event that requires a sequence of gestures to place objects and materials in a meaningful order, sometimes at specified times of the year and specific locations, as the person preparing the offering seeks to engender an exchange relationship with the Earth Beings of the Andes. After introducing these concepts in the first part of the essay, I present descriptions of the use of conopa in the Inka and early colonial periods and then offer a preliminary analysis of Inka and colonial conopa held in museum collections in order to discuss how the interventions of the Inka state and Spanish priests affected changes in household rituals.

\section{REPRESENTATION AND MINIATURIZATION IN ANDEAN ANIMISM}

Clear representations of people and animals are rare in Inka material culture, particularly in the heartland of Cuzco, where the Inka state emerged around AD 1300 
before expanding to form an empire that stretched from northern Ecuador to northwest Argentina until the Spanish conquest in AD 1533 (D'Altroy 2015; Shimada 2015). Much more figurative and representational art had occurred in the ceramics, architecture, and textiles of earlier Andean states, such as Moche, Nazca, Tiwanaku, Wari, and Chimu (Stone-Miller 1995). But Inka ceramics are mainly decorated with patterns that look geometric; Inka stone and adobe architecture was occasionally adorned with colored geometric patterns, and most sculpted stone was in geometric shapes. Instead of using explicitly figurative iconography to spread their ideology, Inka rituals at shrines and administrative sites focused on ritual performance in constructed spaces and landscape features rather than idols. Inka textile designs also look geometric or abstract. However, geometric, colored, or even plain forms could convey quite specific and emotive messages. Abstract and geometric weaving designs today are said to represent agricultural and pastoral features (Silverman 2008), and Inka geometric tocapu textile designs may have conveyed calendrical, social, and topographic information or signified administrative, military, and ritual duties as well as ethnic affiliations (Silverman 2012). The choice of materials used to make objects could also be meaningful. Stone had a particularly powerful significance, and many colonial documents and modern ethnographies highlight how stones are considered animate in the landscape (Bray 2014; Dean 2010). Although hard, cold, and motionless stone would appear to be the antithesis of human life, within Andean animism it is conceived to have energy and a capacity to act, associated with both the origins of life and human ancestors (Lau 2016). Paternosto (1996:186) has argued that the Inka reverence for the natural environment, especially stone, and the primacy of textiles led to an aesthetic of "archetypal geometry" in which meaning was conveyed by materials and form rather than figurative representations.

The Inka did, however, use more realistic representations of animals in a few specific locations: duck heads on small pottery plates used for offerings, a puma head as the central knob on the Inka state beer jars, snakes and pumas carved in stones associated with Inka rulers and divination, and gold and silver representations of maize and camelids were reported at the central Inka temple in Cuzco, Coricancha (Figure 2). Although figurative iconography is rare, the production of small human and animal figurines and miniature reproductions of objects had an important role in Inka rituals. For instance, the Inka prepared elaborate royal offerings (capacocha) that could include the sacrifice of youths aged between 5 and 15, accompanied by miniature gold, silver, and shell statuettes of people clothed in fine miniature textiles and featherwork (Dransart 1995), as well as representations of camelids in silver, gold, and shell, and a range of small-scale pottery vessels and wooden drinking cups (Cobo 1990 [1653]:154; Reinhard 2005). This raises a central question: Why were miniatures that included figurative forms used in Inka offerings when figurative art was so rare in the rest of Inka period material culture? One component of this question that I have previously discussed (Sillar 1996, 2009) is that Andean miniatures are understood to have a vitalizing and regenerative force similar to children and 


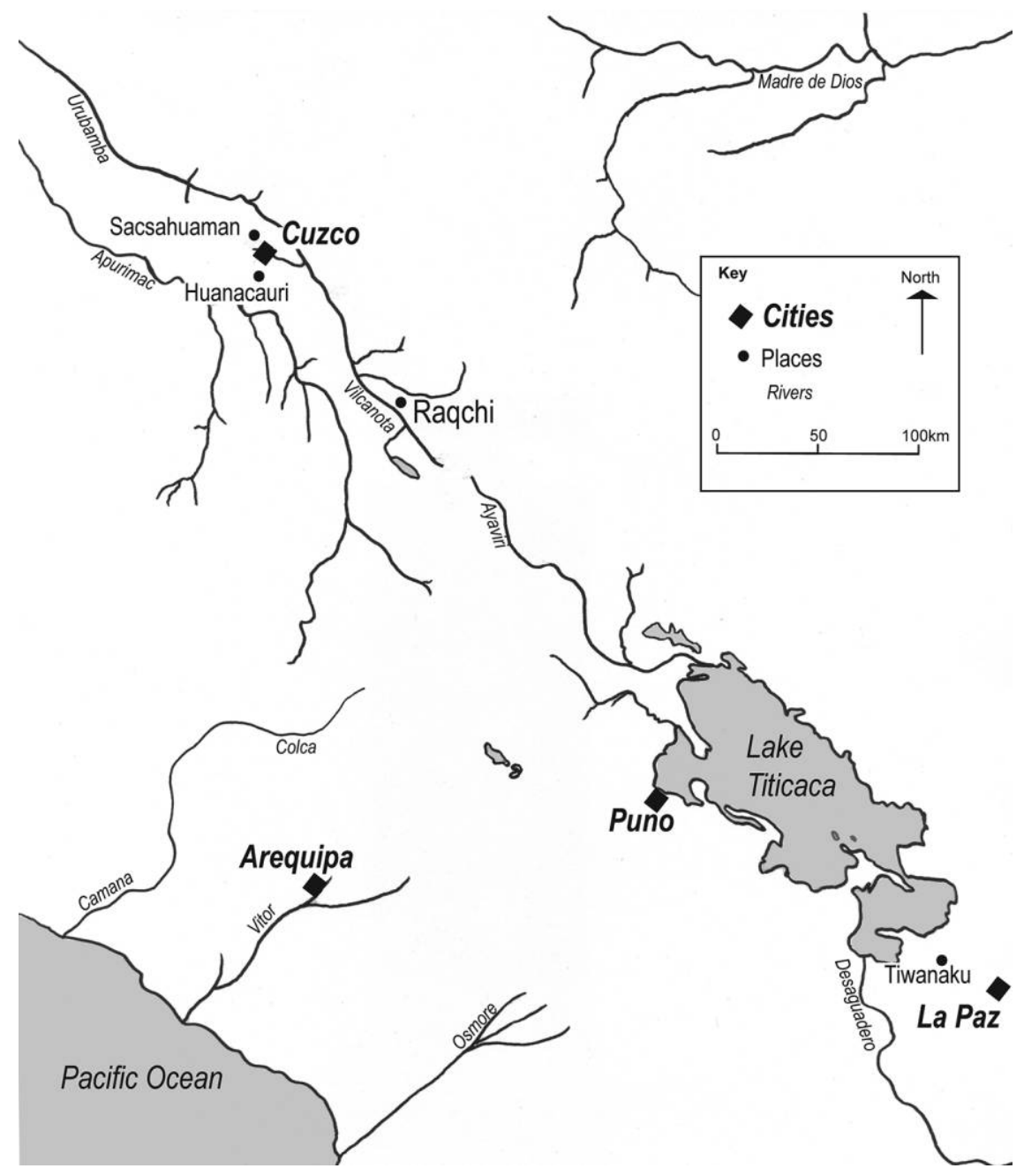

Figure 2. Map showing locations mentioned in the text.

seeds. The use of miniaturized representations of people, animals, and plants in the preparation of offerings would have been particularly powerful within the largely nonrepresentational art of the Inka, and I suggest that this relates to the communicative power of representation within Andean animism. It is what Taussig (1993:2) has referred to as "the magical power of replication, the image affecting what it is an image of, wherein the representation takes power from or shares power with what is represented," with the representation of a single llama potentially evoking wider connotations, such as herding, pasture lands, and productivity, that go beyond the individual animal being represented. Inka figurines were not primarily made for 
humans to view. For instance, the mountaintop capacocha sacrifices were not witnessed by many people, the offerings were directed toward the mountain, and their composition is best understood as an act of communication between the Inka and the sentient mountain (although public knowledge of these audacious offerings added to the reputation of the Inka).

Miniatures play a significant role in present-day ritual practices in the southcentral highlands of Peru and Bolivia. Each year, starting on January 24, the Bolivian capital of La Paz celebrates the Festival of Alasitas. Traders sell a vast array of miniature trucks, houses, construction materials, food produce, computers, mobile phones, money, passports, educational degree certificates, airline tickets, credit cards, and so on. During the festival, people can buy these miniatures from the traders with the national currency, sometimes acquiring them for themselves or giving them as gifts, but frequently people on the street exchange the miniatures with others, acting out elaborate trading banter as they swap wads of miniature dollars for model cars or houses. Most people will take these miniatures home to give them to Ekeko, a hunchbacked figure of a white trader; a cigarette is put in his mouth and lit each day during the month-long festival and (ideally) each Friday for rest of the year. Ekeko is demanding: if the diminutive figure does not have his cargo augmented with further miniature goods, his ambivalent powers may turn against the lax devotee and bring misfortune to the household. But if he is treated with appropriate devotion and nurtured with offerings and cigarettes, he can bring wealth and abundance to the household, transforming the idealized miniature items into reallife goods and benefits. Although the festival is now characterized by the detailed reproduction of miniaturized goods made by artisans, at many pilgrimage sites and mountain passes miniature houses are built out of pebbles picked up from the hillside by the pilgrims themselves. These simple transient structures vary greatly in size and complexity and may include a pebble corral with pebble animals. The houses are both a gift to the miraculous shrine and also indicate a request for a similar (fullscale) house and herd of animals for the devotee (Allen 1997; Sillar 1996).

Another tradition is the preparation of burnt offerings for health, herds, agricultural productivity, business enterprises, or travel. Miniatures and representations made out of sugar and lead are positioned on a white sheet of paper, and coca leaves are placed into the bundle before placing it on a fire (Fernández Juárez 1997; Martinez 1987). These burnt offering are referred to in Quechua as a dispachu, a loan word from Spanish meaning something that is sent. The alasitas, pebble houses, and dispachu offerings are "sent" or "dedicated" by directing them through the timing, location, and composition of the offering and by making libations and verbal evocations to nonhuman recipients (Allen 1982:191; Sillar 2000:372). The people preparing the offerings seek to communicate their concerns and aspirations by selecting, positioning, and naming materials and objects.

As Taussig (1993) highlights, this is a sensual participatory experience that involves touching, looking, tasting, smelling, listening, and speaking. The significance 
of Andean miniatures and figurines comes not simply from what they represent, but from their active role in composing offerings. Each object, material, gesture, and evocation contributes an ingredient to the offering, and the final result depends on the sequence and arrangement of the ingredients (see Pitrou 2015). The role of miniaturization and synecdoche (taking part of something to represent a larger concept or whole) allows the person preparing the offering to manipulate and communicate with larger-scale, more distant nonhuman entities by positioning handheld things.

These modern rituals provide a useful route into our consideration of Inka miniatures, where not only did the form of the object imitate large-scale counterparts, but colonial references suggest that they also formed components within a series of ritual acts that were used to communicate with nonhuman entities (Cobo 1990 [1653]:115-17, and see below). I use the term nonhuman, rather than supernatural, to refer to animate powers recognized in the Andes, such as the mountains, lakes, stone huacas, saints, houses, and fields, which are considered sentient beings. However, de la Cadena (2014) cautions against creating a divide between humans and the rest of the material world, stressing Viveiros de Castro's (1998) observation that Amerindian languages discuss the physical and social position of the subject in relation to other referents rather than specifying humans as a separate species. Amerindian world views are primarily conceptualized through relationships of codependence rather than a Cartesian view of the uniqueness of human agency. Highland Peruvians use the term tirakuna, composed of the Spanish tierra and its Quechua pluralization kuna, which de la Cadena (2015) translates as "Earth Beings," highlighting the materiality of the mountains, stones, fields, and springs, and including some man-made objects, such as buildings, bridges, and crosses. These material entities are understood to be active agents that can influence the productivity, health, and well-being of humans. Working near Cuzco, de la Cadena (2015) was told that Andean people (runakuna) only live, eat, and reproduce through their engagement with the land; this was explained as a reciprocal exchange and mutual co-creation between the runakuna (local indigenous Andean people) and the tirakuna (Earth Beings) that informed and influenced all activities, including political activism in Cuzco and Lima and the ability to reclaim land from the control of hacienda owners.

Within this animistic understanding, Andean miniatures are more than mimetic representations or imitations of larger objects; they also have an active connection with and influence on the things and ideals they represent. Frazer (1915) used the terms "homeopathic magic" to describe the concept that like influences like (similarity) and "contagious magic," in which things that have once been in contact continue to act on each other at a distance (contagion). These principles of similarity and contagion (including miniaturization and synecdoche) are fundamental to Andean animism (Allen 1988; Sillar 2009; Stensrud 2010). Although Tylor (1913 [1871]) defined animism as the belief that an entity has a soul or animating spirit, the attribution of animate properties to nonhuman entities does not require a belief 
in a "soul" that is somehow beyond nature (Ingold 2006). Animism focuses on how people are a part of their environment and able to communicate with it, with places and things having a vital force or identity that is similar to rather than different from humans (Harvey 2005; Hornborg 2006). "Andean people do not separate the natural from the spiritual environment. They believe that, like animals and people, all elements of nature live" (Bolin 1998:43).

Marett (1914) adopted the Melanesian word mana to describe this vitalizing force, and the equivalent Andean expression camay refers to an animating force that resides in and activates living things, including material objects (Bray 2009; Sillar 2009). Bird-David (1999) uses the term "relational epistemology" to describe how people, places, and things are understood to communicate with each other, and although she is referring to hunter-gatherer concepts, this is also how many Andean people express their understanding. Highland Andean people do not describe the animate world by using terms such as "god" or "supernatural"; rather, animate forces are physical entities that are visible, named objects or landscape locations described as being interrelated within hierarchical relationships similar to those in human society (Bray 2014; Rostworowski 1986). For instance, the huaca of Huanacauri, one of the most important objects of veneration for the Inka, was overlooked by the Spaniards when sacking Huanacauri's cult site because they only saw a "rough stone" (Cobo (1990 [1653]:74). Yet this "rough stone" was also understood to be the petrified body of Ayar Cache, a founding ancestor of the Inka lineage that was central to the initiation rites of Inka elite youths. The fact that material objects and places could be drawn into human kinship shows the interrelationship between humans, places, and things in the Andes of the fifteenth century. This relational view of interdependence and communication between human and animate nonhuman entities is embedded within a moral conception of social obligations (cf. Descola 1994).

The construction of Andean offering involves a careful choreography of meaningful and animate materials. It is the process of bringing a range of objects and ingredients together and the verbal evocation of people, places, and things that activates and directs the offering. Objects that feature in household rituals today include small carved stone animals that are inherited or bought at annual pilgrimage sites, as well as various "found" objects such as unmodified stones and pieces of glass or pottery (Figure 3). These objects are referred to today as enqa or illa and are considered to be living entities that support animal and crop fertility (Allen 1988). Illa and enqa are described as children of the sentient mountains, which are referred to as apus (Isbell 1985; Sillar 1996), or as coming from Ukhu Pacha (the inner world), emerging from caves or springs (Flores-Ochoa 1979:84), and they are said to remain in communication with the mountain apus that they came from (Skar 1994:65). Illa are not for public display; they are kept hidden in the house (usually wrapped in cloth) and are carefully protected for use by household members. They are cared 


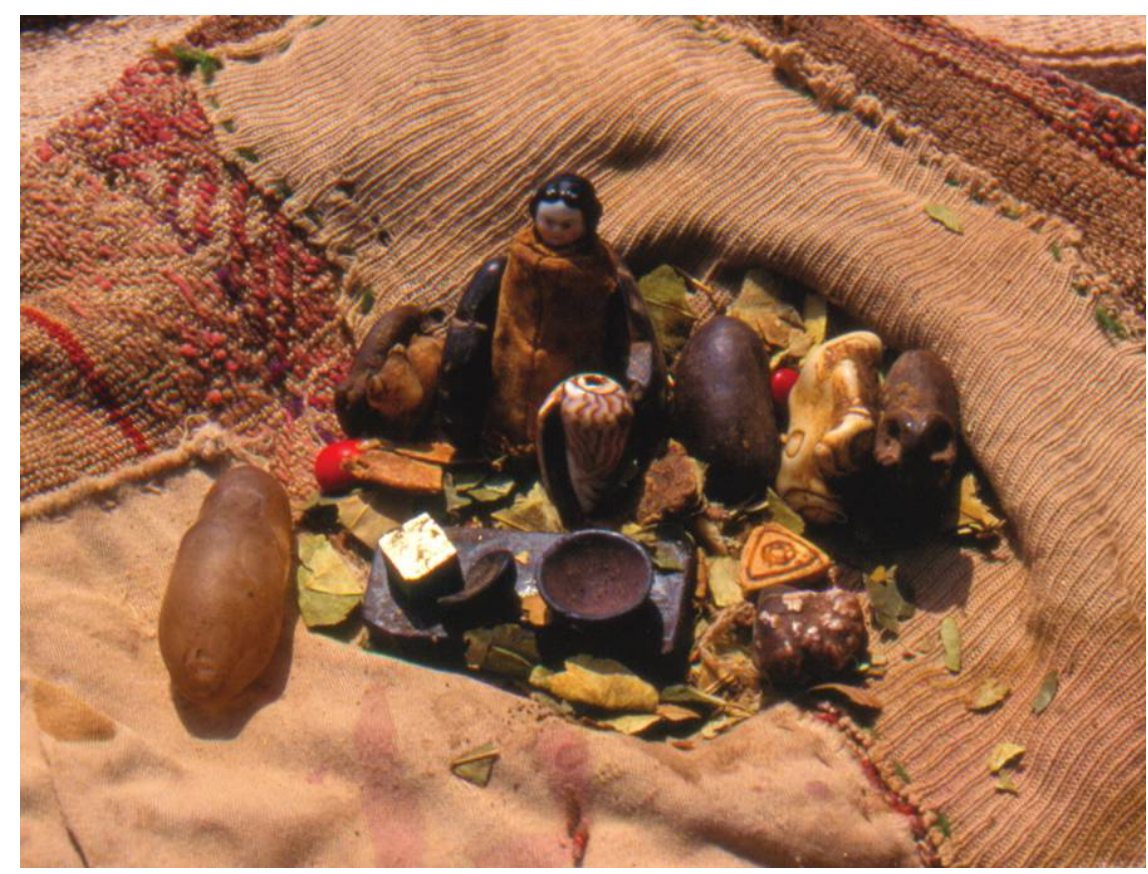

Figure 3. Ritual bundle including both found stones and carved animal illa. These illa are in position at the start of preparing a dispachu offering. Most of the objects in this bundle were inherited by the father when he inherited the house from his father (Raqchi, Dept. Cuzco, Peru).

for by the family, and at least once a year they are brought out to participate in the preparation of a household offering. I have participated in some of these household rituals in Raqchi, Department of Cuzco (Sillar 2013). The preparation of these offerings varies considerably, but typically it is composed of small bundles ( $k^{\prime}$ intu) of coca leaves, each of which is dedicated to a named recipient (e.g., house, hearth and stored goods, fields, pastures, paths, roads, clay mines, and market places), and each coca leaf bundle can be placed alongside a maize kernel and small piece of animal fat (vira). After the offering is completed, it is taken into the household patio, animal coral, or field to be sent as a dispachu to the apu by being burnt (the complete burning of the offering shows it has been fully accepted). The offering brings together a wide range of important locations through evocation; the offering materials include maize from household fields, fat from their animals, chich (maize beer), alcohol, and coca leaves to feed the mountain apu. It expresses a commitment to work with the land and herd the animals, and it requests the continuing support of the apu in caring for the house, stores, animals, crops, and trading activities. During rituals, the illa are said to drink the chicha and chew the coca given in the offerings (Allen 1988:54, 150). 
Whereas Weiner's (1992) analysis of inalienable possessions focused on how objects remain connected to previous human owners, Andean animism stresses how objects are connected to the source of their raw materials, visual representation, as well as prior connections to a person, place, or thing. Frazer (1915) described his principles of homeopathy and contagion as components of sympathetic magic, and although I do not favor the term "magic," "sympathetic" is a highly appropriate descriptor for the connectedness (the "concern" or "attachment") that is thought to exist between physically separated things. The components of an offering are brought together from a wide range of environments and contexts in order to influence the animate forces of the material world (Bolin 1998:40-41; cf. Zedeño 2008). Just as people remain connected to their family through kinship obligations and concerns, so too the Andean "inalienable character of things" means that objects can continue to exert an influence on their origin or referent. Places and things are considered to have a social relatedness similar to those surrounding human kinship. For this reason the little illa are interlocutors that can communicate with their mountainous lithic origin as well as with the animal herds, crops, and houses. Illa consume the coca, alcohol, fat, and maize themselves and direct these offerings to the mountain apus; in turn they bring vitality back from the mountains so that herds procreate, crops are productive, and humans are healthy. Illa are carefully guarded and passed down for generations. In Raqchi they usually stay with the child who inherits the family house, although Catherine Allen (personal communication 2015) has heard of carved stone illa being split so that the two parts can be inherited by different family members.

\section{CONOPA AND THE SPANISH COLONIAL EXTIRPATION OF IDOLATRY}

Holguin's (1989 [1608]:366) Quechua dictionary from shortly after the Spanish conquest defines illa as a notable stone that may be bright and shiny or found in the stomach of an animal and is kept for riches and luck; the alternative spelling, ylla, is described as all that is old and guarded for many years, while yllayoc runa is a rich person who has and guards tesoro (treasure). This suggests that illa is a category of objects and ideals that antedates the Spanish conquest, although Holguin's description appears to prioritize found objects and may not refer to carved stone amulets. The word most commonly used in early colonial documents (and still used in the Apurimac area today) to describe these ritual objects is conopa. Colonial sources describe them in terms very similar to the modern illa from Raqchi. Arriaga (1999:36 [1621: ch. 2]) explains that a conopa could be a found stone or other material with an unusual color or shape, but also stones carved in the form of llamas, maize, or potatoes, and so on. Although conopa can be made from many different materials, they are mainly described as stones. Stone is a particularly evocative, powerful, and primordial material within Andean cosmology, associated with the origins of people 
and animals as well as the powerful mountains (Bray 2014; Dean 2010; Paternosto 1996). Carved stone conopa and illa made from small pieces of "living rock" combine miniaturization and synecdoche, allowing the user to "hold the land in their hand." Seventeenth-century priests reported finding many Andean people in possession of conopa. Some conopa were dedicated to the care of crops and animal herds, while others were for the well-being, wealth, and protection of the household (Mills 1997). As with modern illa, colonial sources state that conopa were guarded as family heirlooms, passed from father to son, and protected "as the most precious thing that their parents had left them" (Arriaga 1999:35 [1621 ch: 2]). Arriaga (1999:36 [1621: ch. 2]) describes conopa as being the focus of intimate household rituals that were held in private at particular times of the year, such as before going on a journey or sowing crops. He lists the use of coca, maize, animal fat, and chicha within the offerings, as well as describing blowing over the coca and burning the offering to dedicate them (Arriaga 1999:50 [1621: ch. 4]). Conopa are not described as being part of the offering, as they are kept and guarded by the household to be brought out for future rituals. "Rare are those who do not have them, for they are the principal inheritance of the family, and sometimes they have two, three, or four of them" (Arriaga 1999:80 [1621: ch. 8]).

Some colonial-period conopa are described as being vessels with a hollowed-out bowl in their backs. Flores-Ochoa (1976:249) observed modern herders who described the indentation in the back of conopa as a cocha (pond/lake) which they filled with animal fat during rituals. Fat (vira) is considered a vitalizing force, and placing the vira into the cocha may have been considered a way to animate or feed the conopa. During a trial in 1656 a native, Hernando Caruachin, described being given a black stone conopa in the form of a man's face with an indentation in the back which he filled with llama fat and a small coin to supplicate for good fortune (Mills 1997:96-97). Combining the vitalizing llama fat with a material component of the new method of exchange that was transforming Andean economic relationships would have been highly symbolic. This is similar to the Inka paccha described by Stone-Miller (2006) made of clay in the shape of a conjoined foot plow, maize plant, and beer jar (Figure 4), which during its ritual use had maize beer (chicha or asua) poured through its hollow form into the earth. "Asua poured through the paccha makes it become an agent of transformation, symbolically activating the earth to grow maize to make the asua" (Stone-Miller 2006:221). Similarly the vitalizing llama fat placed into the cocha (bowl) of the conopa made it an agent of transformation, symbolically feeding the mountains to encourage the health and fertility of the llama herds. It is likely that the stony materiality (and landscape source) of the conopa was just as important as its camelid shape in making a link between the llamas and the Earth Beings that care for them. Vira-cocha is the name of the Inka animating force, sometimes personified as a man who walked over the earth and brought people and animals out of the land at various places of origin (Betanzos 


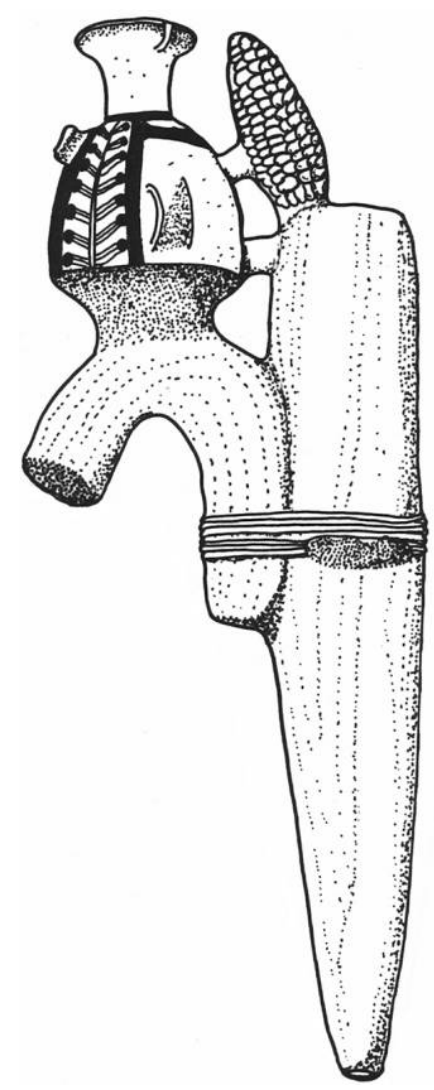

Figure 4. Inca period ceramic paccha in the collection of the Michael C. Carlos Museum, Emory University, Atlanta, Georgia. This paccha is $37 \mathrm{~cm}$ high and formed in the shape of a foot plow (taclla), maize cob, and beer jar (urpu); the hollow center had maize residue (Stone-Miller 2006; drawing by Bill Sillar).

[1557] 1996:9-11). The simple act of placing camelid fat into the hollowed-out space of these small carved stones may have been as transformative and meaningful as a Catholic priest holding aloft a small circle of bread.

Catholic priests such as Arriaga (1999 [1621]), Albornoz (1989 [1584]), and Hernández Príncipe (1923 [1621]) were seeking to locate and eradicate (extirpate) indigenous religious practices (which they considered idolatrous). Objects considered to be idolatrous were gathered together and burned or destroyed in public, often in the village plaza. For instance, Arriaga (1999:23 [1621: ch. 1]) reports that between February 1617 and July 1618 Hernando de Avendaño hunted down and destroyed 3418 conopa. During this period, it was perilous to possess conopa. The Spanish extirpation of idolatry restricted these rituals to the private and protected space of the family home, where Andean people continued to express their commitment to 
the animate landscape in defiance of colonial aggression and Catholic dogma. But in spite of Spanish attempts to extinguish native ritual practices, illa and conopa were protected in many households, and their material presence provided a vehicle for the continuity of some aspects of native Andean cosmologies and cultural values.

Prior to the Spanish interventions, conopa may have been more visible. Arriaga (1999 [1621: ch. 2]) describes huaca as shrines such as rocks and sacred points in the landscape that were worshiped communally and in public (Cobo 1990 [1653]; Dean 2010); he contrasts them with conopa, which he states were worshiped by the household in private. However, he also describes conopa that were found next to huaca: for instance, he quotes Licentiate Rodrigo Hernández, who discovered a stone huaca in the form of a falcon surrounded by many conopa that served as servants or criados (Arriaga 1999 [1621: ch. 10]). Similarly Hernández Príncipe (1923 [1621]:27) discusses how herders kept their conopa above their old village, next to a cult place for lightning. Silverblatt (1987:199) says the Spanish priest Father Avendaño removed a stone idol in the form of a man with five conopa around it placed at the base of a molle tree. The excavators of Cochapata, part of the Sacsahuaman archaeological park, interpret this modified stone outcrop as a huaca that was deliberately destroyed and backfilled in the colonial period, and they found four carved camelid conopa associated with the site (Rodríguez Limache 2009). Perhaps conopa were being placed next to huaca in order to benefit from the contagious effect of each other's identity and animate agency. Albornoz (1989 [1584]:171) describes how the power of a huaca could be reproduced; for instance, a cloth that had been laid on the original huaca could be placed on a distant stone, thus transferring the animating force, camay, to a new huaca, which took on the name of the original. It seems likely therefore that the placing of conopa near a huaca was intended to facilitate communication through a form of contagious contact. References to conopa being found next to huaca suggest that in the Inka period there was an interaction between the community or regional recognition of the huaca and the more intimate, familial association of the smaller, handheld conopa. As mobile objects, the conopa were probably only placed next to a huaca for a limited period, but this may have created a permanent association or relationship between the conopa and the huaca. This association and the biography of the conopa would probably be recalled during rituals; it is even possible that some conopa were from the same lithic material as, or imitated the form of, huaca.

\section{INKA CONOPA IN MUSEUM COLLECTIONS}

Given that illa and conopa can be formed from a wide range of materials, including unmodified stones, how are we to identify Inka conopa? The category of object that is most commonly identified as conopa by archaeologists and museum curators today are carved stone camelids with a hollowed-out bowl in their backs. There must be well over a thousand of these carved stone camelids in museum collections and private acquisitions around the world. With the help of Stevii Marshall and 
Cesar Astuhuman, I have so far recorded and analyzed only 97 of these carved stone conopa, from the collections of the Museo Inka, Universidad San Antonio Abad del Cuzco (UNSAAC); Museo de Antropologia y Arqueologia, Lima; the Field Museum, Chicago; the American Museum of Natural History, New York (AMNH); the British Museum, London (BM); and the Museum of Archaeology and Anthropology, Cambridge. Very little information about the original provenance or date of these museum acquisitions is known. However, a small number of the llama and alpaca conopa in the UNSAAC collection were excavated from Inka contexts at Sacsahuaman, and the majority of that collection comes from the Cuzco vicinity, as does the majority of the collection acquired by Emilio Montez held in the Field Museum (Bauer and Stanish 1990:2-3). There are also small carved stone representations of maize cobs in these museum collections that were probably conopa, and the Montez collection in the Field Museum includes several rude stones with faces carved on them. AMNH has a box of unmodified stones of diverse materials and shapes, which Bandelier recovered as a cache on the Island of the Sun, Lake Titicaca, Bolivia. Thus there is some hope that we could begin to analyze a wider range of objects that served as conopa or illa. But, for the moment, the stone camelids provide a more secure starting point from which to discuss the materiality of Inka conopa.

The objects in the study group were mainly carved in the shape of llamas or alpacas, ranging in length from 5 to $15 \mathrm{~cm}$. Even within this restricted and biased sample of 97 objects there is significant variability in the choice of stone, the quality of carving, and the size and shape of the animal. It included a colonial form with a human face, another with a pumalike face, and one in the process of giving birth. It is likely that several date to the colonial period and some could be even more recent. One distinguishing feature for later conopa is that the basin in the back has vertical sides formed by drilling, whereas the basins in the Inka period (and probably some in the colonial period) conopa have concave sides that were "chiseled" out and are wider on the inside than they are at the surface, creating a somewhat spherical shape. In a few examples these hollowed-out areas have a darkened appearance. A few examples have fat preserved in the hollow (Figure 1), although these are likely to be Inka or early colonial period artifacts acquired from more recent ethnographic sources. In relation to the minimal use of naturalistic and representational art in Inka material culture, these conopa are unusual for the clarity of camelid representations, but they are also recognizable as stone objects and the concavity carved in their backs draws attention to their active role as objects that were handled and interacted with.

Many of these conopa appear to be "one-offs" and were probably found and carved by their owners. They were probably made from unusual stones that attracted the gaze or "charmed" the attention of the finder. Several conopa have distinctive coloration and banding (Figure 5), and it seems likely that these stones were identified and chosen because they reflected the symbolism of llama fleece patterns and coloration, which were important features in the selection of llamas for sacrifice 


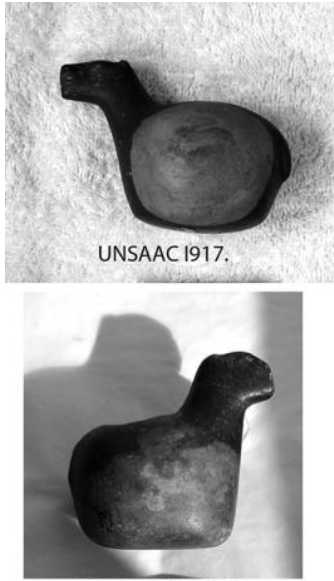

BM Am 1925, 5-5.1
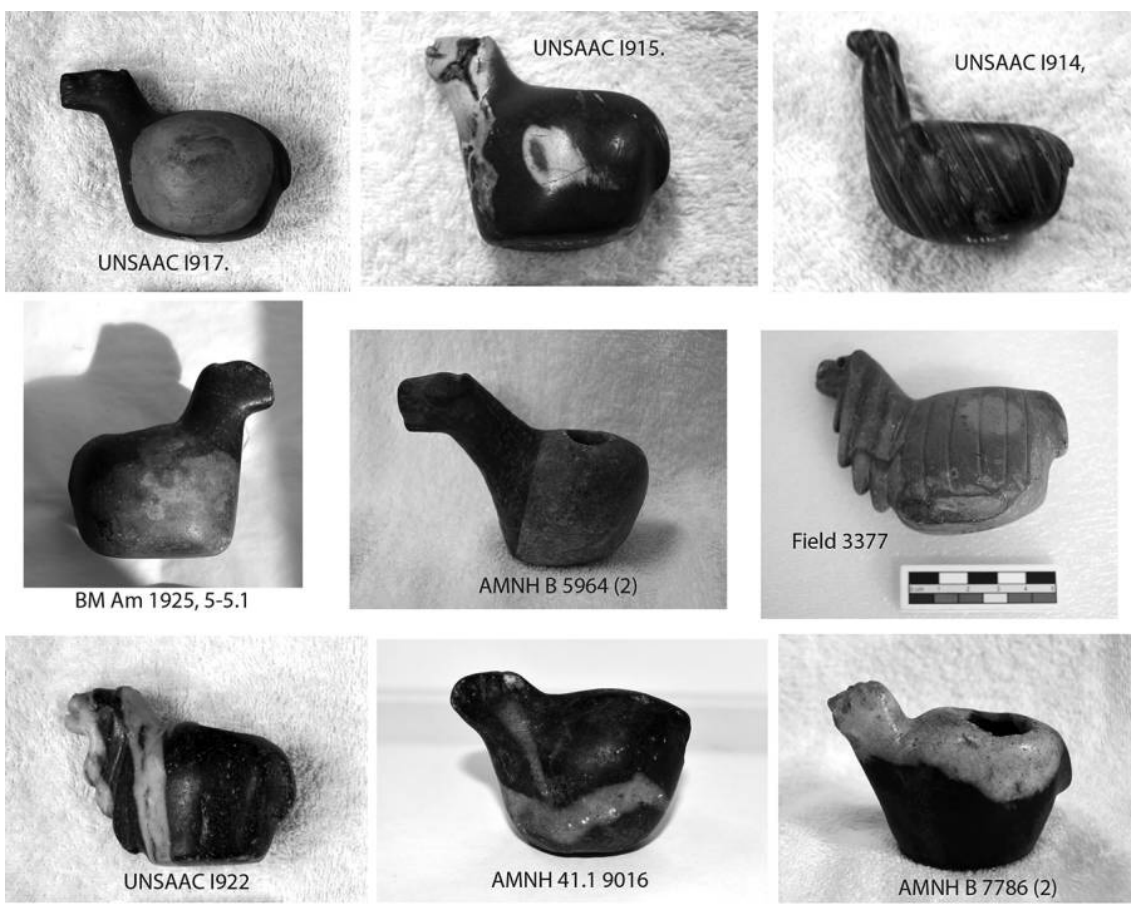

Figure 5. Nine examples of bicolored conopa (with museum accession numbers).

(Cobo 1990 [1653 v. 13, ch. 21]:113). The term allqa can be used to describe a camelid with a juxtaposition of contrasting dark and light colors (Dransart 2002:70; Flores-Ochoa 1986:142), and the term is also used to describe textile designs (Cereceda 1986:160). Prior to the influence of commercial markets in the eighteenth and nineteenth centuries, white-fleeced llamas and alpacas were much less common (Flores Ochoa 1986:147), and bicolored fleeced animals are valued by native herders today. Cereceda (1987) highlights the juxtaposition of contrasting colors, seen as a thing of power and beauty that is sometimes considered productive or lucky (Stobart 2006:82). This may help explain why bicolored stones were selected, with the orientation of the carving purposefully positioning the stone coloration in relation to the animal form.

Recognizable groups of conopa are made using the same raw-material sources and carved using similar forms and techniques, which suggests organized production and distribution. For instance, ten made from a highly polished dark green stone (Figure 6) are carved with particularly bulbous, round bodies; six of them have distinctive, deep, but slightly rounded indentations to represent the fleece around the animal's neck. A preliminary look at their chemical composition, as measured by portable X-ray fluorescence, shows that this dark green group has a distinctive high iron content (30-40\%). Another group of at least 12 conopa are dark 


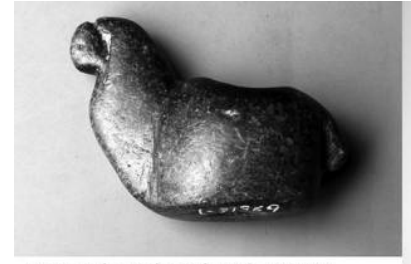

Museo de Arch and Anth L21369

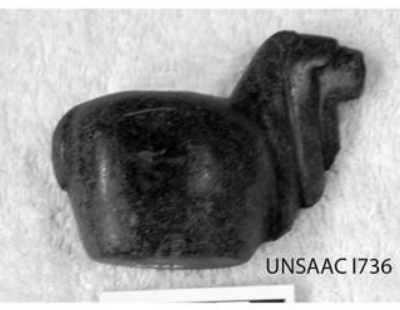

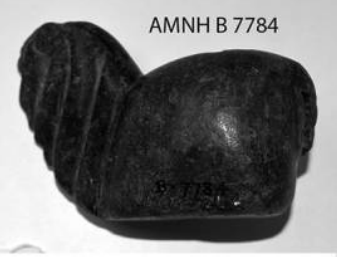

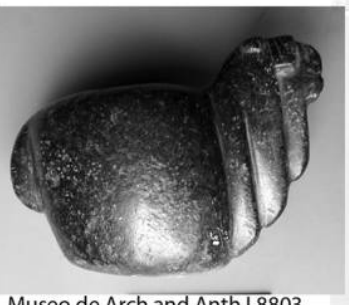

Museo de Arch and Anth $L 8803$

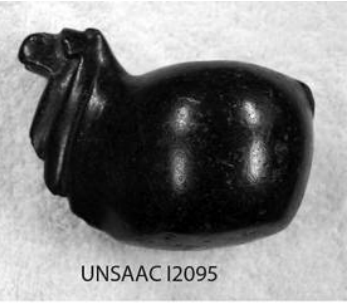

UNSAAC 12095

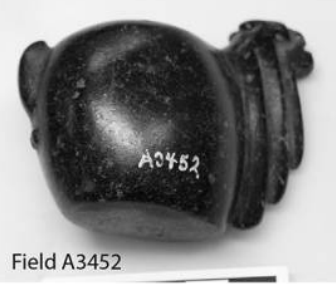

Field A3452
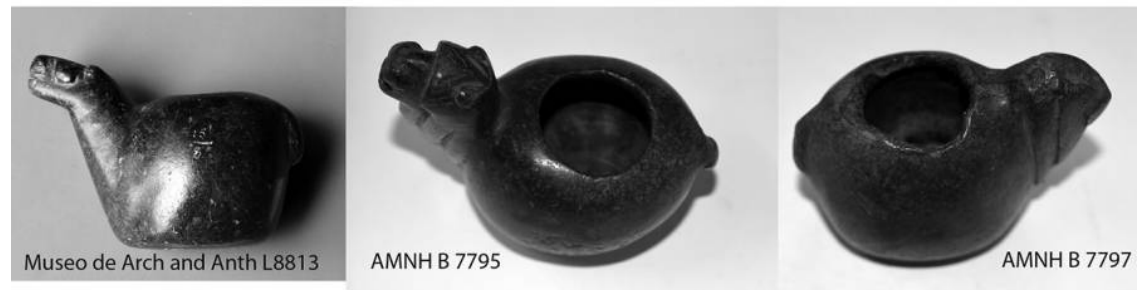

Figure 6. Nine dark green conopa (with museum accession numbers).

gray-black (Figure 7) and carved with slightly slimmer oval bodies, with the neck fleece represented by angular, straight-edged indentations; these are usually highly polished (with iron content around 1\%). One example of this group of black conopa was recently excavated from a secure archaeological context in a house from the Inka period occupation at Qotacalle (excavated from recinto 24 capa 4; Amelia Perez Trujillo, personal communication August 2015; see Figure 7). Another (AMNH B3668) appears to be in the final stages of production, with deep incisions made in the neck, but the stone has not yet been removed to form the carved indentations seen in other examples, and it has not been polished. From casual observation of collections of conopa on display at these and other museums (which have not yet been analyzed) I have seen at least another eight of the dark green and another 20 of the well-crafted dark gray-black style. This organized production of conopa is distinct from the rather individual relationship to "found objects" described by most colonial sources.

The fact that many of these artifacts come from collections made in and around the Inka capital of Cuzco suggests that the Inka state was involved in their distribution. In the absence of market trade, this is likely to have required some institutional 

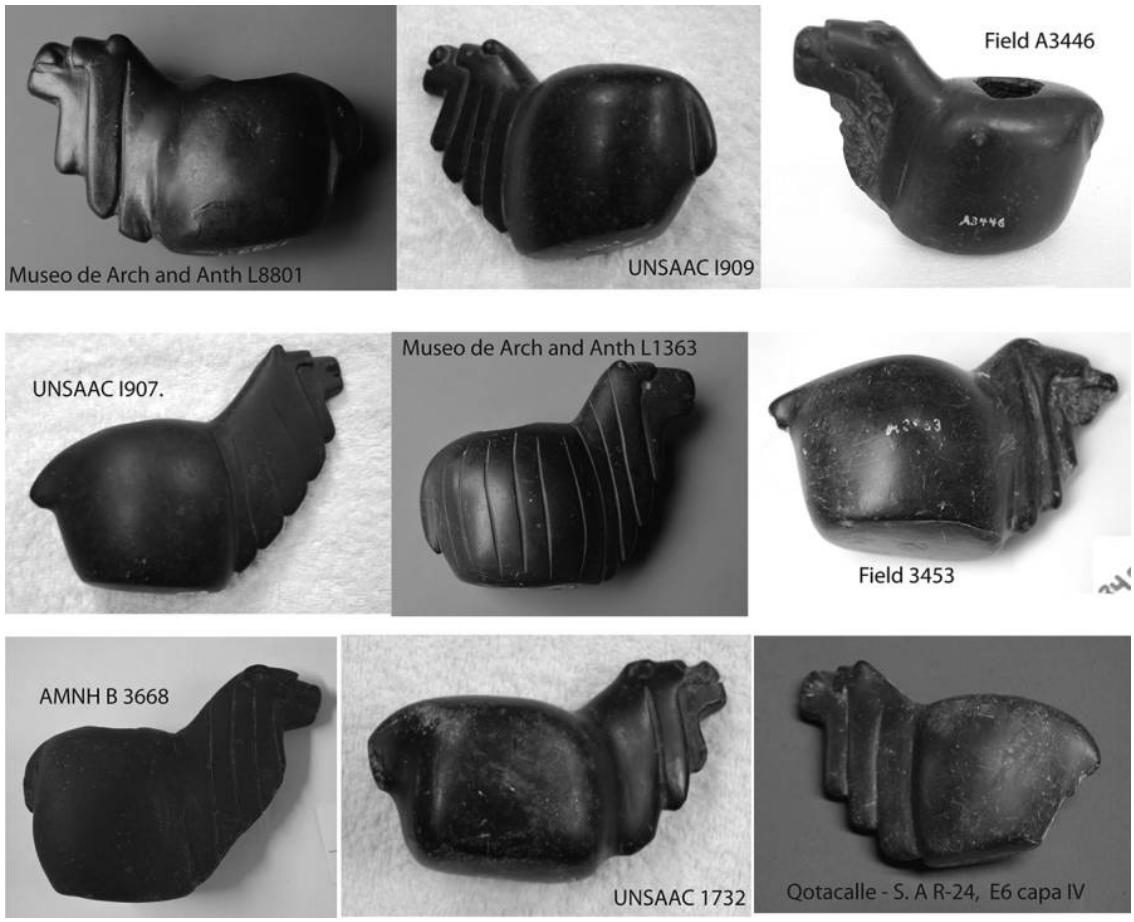

Figure 7. Nine gray/black conopa (with museum accession numbers); the conopa on the bottom right was excavated from the Inca site of Qotacalle, Cuzco, Peru, during excavations directed by Amelia Perez Trujillo.

involvement in the production of these conopa, with their circulation taking place within some aspect of the redistributive and reciprocal features of the Inka economy. Luis Millones reports on an idolatry trial in Lima in 1646 in which an Indian, Diego Guman Poma, confessed to having a small crystal stone conopa which he had protected for a long time. He called the conopa "Mayquanco" and regularly gave it food and drink. Diego Guman Poma explained that this conopa was given to him by a high-ranking aqlla (a woman chosen to work for Inka state religious institutions) in Cuzco: "que se la habia dado una Palla del Inca llamada Aclla en el Cuzco" (Millones 1989:27), supporting the suggestion that conopa were sometimes distributed by state officials. This raises interesting questions about how the Inka state interacted with the development of these "domestic" rituals. Inka involvement in the production and distribution of conopa need not mean that they were any less animate. An association with state rituals, the aqlla, and prestigious huaca may have made these carved conopa as powerful as any stones found by herders. The gift of a conopa from Inka officials to trusted workers and its association with state rituals could have added to its power. 
Cieza de León (1967:101) describes an annual census of camelid herds undertaken by the Inka in November that was integrated with a ceremony to help the herds multiply; conopa could have been used and distributed during such a ceremony. Within the Cuzco heartland the yearly round of rituals associated with the 328 springs, rock formations, and landmarks that were identified as lines of huacas radiating out from Cuzco (Cobo 1990 [1653]; Bauer 1998) could provide another context in which conopa were distributed or materially connected by placing the conopa next to the huacas. The fact that carved stone conopa are not found with the miniature objects that accompany Inka capacocha and other placed offerings supports the suggestion that conopa (like modern illa) were intended to remain in active service within on-going ritual activities rather than forming part of the offering itself. Distributing conopa to the wider population could have been a powerful tool of Inka largesse that would bring the state into the core of household identity and the intimacy of repeated family/household rituals, as suggested by the black conopa found in the Inka period house at Qotacalle.

\section{CHANGE AND CONTINUITY IN THE ACTIVE ROLE OF ANDEAN MINIATURES}

Perhaps we should not assume that the Inka only used small-scale representations for rituals. Garcilaso (1989 [1612]:124) states that at the quarry of Muina, five leagues from Cuzco and now named Rumicollca, he saw a small-scale model of Cuzco's streets and buildings made in pebbles, sticks, and clay. The primary purpose of this model was probably as an architectural maquette to help plan building works. Nonetheless, the restricted use of representational art within Inka culture made the limited use of representation in miniatures particularly powerful, and their use in Inka ritual suggests they were vested with an ability to engage with the animate world. Perhaps creating a miniature representation of a new building in Cuzco was meant not only to help plan the work, but also to be used as a mechanism to request the active support of the stone source in accomplishing the building project.

What is clear from the above discussion is that representation and miniaturization within Inka material culture were not simply used for decorative purposes. Conopa were active components within a system of communication. Their form and materials created sympathetic links between the supplicant's aspirations and the animate powers of the Andean world. Further research into the form, materiality, and composition of Inka material culture provides an opportunity for researchers to reconsider how the Inka used their engagement with this animate world for strategic political ends.

I believe that the production and circulation of carved conopa was encouraged by the Inka state, and that these rituals became confined to the domestic sphere because of the Catholic extirpation of idolatries. I suspect that ritual use of illa-type objects to bridge a relationship between people and the animate landscape had a long history in the Andes, particularly among herding communities. It is also likely that the camelid form with the concavity in its back draws upon earlier traditions (ce- 
ramic forms made by Wari and Tiwanaku potters show some similarity; Glowacki 2012:150). However, the production of carved stone camelid conopa is primarily associated with the Inka, and large numbers were produced in the Cuzco region during the Inka (and probably the early colonial) period. At one time conopa circulated more openly and probably formed a link between Inka state, local huaca, and household or herding rituals. But during the colonial extirpation of idolatry, these practices became dangerous. They could only be continued as clandestine activities confined to the household, possibly adding to the care with which illa and conopa were hidden and protected. Outside the house the ritual focus of Andean animism in the colonial period moved away from public rituals associated with named huaca but continued in agricultural and herding rituals as well as focusing on more distant and indestructible features of the landscape, such as mountain apu (Gose 2006). Although the physical and visual properties of illa are appreciated and sometimes commented on, they are not display items; they are curated for private household use. The aesthetic properties of offering components and the sensory engagements with sight, sound, and smell need to be considered from both the human and the nonhuman perspectives. The preparation of offerings, to which the illa bear witness, is a private performance that involves the choreography of meaningful materials and the evocation of people, places, and things that are of concern to the family. Yet as small-scale agriculture and herding become increasingly difficult to sustain, and Andean people change their aspirations in relation to globalization, urbanization, and wage labor, the illa and the intimate rituals that linked people to their work on the land are becoming less relevant. However, far from leading to the demise of miniatures in Andean ritual practice, urban populations have brought their ritual use of miniatures back into the open to express their hopes and aspirations. The public spectacle of people buying and exchanging miniature model houses, cars, and wads of miniature dollars in $\mathrm{La} \mathrm{Paz}$, and taking them into the cathedral for a blessing from the Catholic priest, may have more in common with taking Inka period conopa to huacas than is at first apparent (Allen 2016; Stensrud 2010).

This article has discussed why miniature figurines can be particularly meaningful within an animistic view of the world. An active connection is made between a small carved stone llama with animal fat on its back and the wider world of sentient mountains, llama herds, and agricultural production. Animism means that the materiality and form of an object is not simply decorative or iconic; miniaturization and synecdoche create active homeopathic and contagious links between a handheld object and the wider landscape. Preparing these offerings is undertaken as a complementary activity to agricultural work and animal husbandry, which are also considered to be acts of communication and exchange with the animate world (Gose 1986; Sillar 2009). No one in Raqchi suggested to me that making these offerings will reduce the amount of time and physical labor they need to put into their subsistence tasks. I hope that my description of animistic ideas and practices has not made these Andean world views too exotic. Discussing how the manipulation of small stones 
is thought to influence mountains and other Earth Beings may have propagated a sense of "otherness" between the reader and these Andean practices (Taussig 1993). But I contend that this acknowledgment of an interdependence between the rural populations of Cuzco and the land where they live and work expresses a moral commitment that is evidently absent from nearby mining companies, who claim that metal ore is a global commodity that justifies large-scale exploitation and contamination of land and water (see de la Cadena 2015). Andean expressions of a codependence between people and nature has more to offer the twenty-first century than the self-interest of a belief in the uniqueness of human agency. Animism locates people as participants in the material world and demands that they take responsibility for their relationship with animals, plants, places, things, and people (Bird-David 1999; Hornborg 2006; Ingold 2006). Andean offerings for people, camelid herds, and the animate land creates a greater sense of connectedness and moral obligation than I gain from watching miniaturized representations on a TV screen or using small bits of paper to vote for political parties. Miniature animal figurines, maize kernels, and animal fat are meaningful and effective for people who are engaged in agricultural work, just as miniature cars, consumer goods, and bank notes are tangible and evocative for those in urban jobs. These diminutive objects are animate because they are materially linked to real-world experiences: handling and positioning these objects expresses the aspirations of hard-working people and maintains their relationship to a wide social landscape.

\section{NOTES}

I owe a continuing debt of gratitude to residents of Raqchi for allowing me to participate in and discuss their family k'intuqwi. I would like to thank the Field Museum of Natural History, Chicago; the Museo Inka, Universidad de San Antonio Abad del Cuzco (UNSAAC); the British Museum (BM); the American Museum of Natural History (AMNH); and the Cambridge University Museum of Archaeology and Anthropology for their help and support as well as their kind permission to analyze a selection of their conopa. I especially wish to thank Ryan Williams, Claudia Pereyra, Jago Cooper, Trisha Biers, Imogen Gunn, Sumru Alincali, and Kate Jarvis for their help in accessing collections and discussing ideas in this paper. I am also very grateful for research input, support, and discussion from the following: Perig Pitrou, Olivia Angé, Paul Basu, Henry Stobart, Cesar Astuhuman, Stevii Marshall, Amelia Perez Trujillo, Andrew Hamilton, Catherine Allen, and Ruth Siddall. I would also like to thank the two anonymous reviewers who provided helpful suggestions to improve this article.

\section{REFERENCES CITED}

Albornoz, Cristobal de. 1989 [1584]. "Instrucción para descubrir todas las guacas del Pirú y sus camayos y haziendas," in Fábulas y mitos de los Incas. Edited by Henrique Urbano and Pierre Duviols, pp. 163-98. Madrid: Historia 16. 
Allen, Catherine J. 1982. Body and soul in Quechua thought. Journal of Latin American Lore 8(2):179-96.

. 1988. The hold life has: Coca and cultural identity in an Andean community. Washington, DC: Smithsonian Institution Press.

_. 1997. "When pebbles move mountains: Iconicity and symbolism in Quechua ritual," in Creating context in Andean culture. Edited by Rosaleen Howard-Malverde, pp. 73-84. Oxford: Oxford University Press.

2016. The living ones: Miniatures and animation in the Andes. Iournal of Anthropolooical Research 72(4):416-41.

Arriaga, Pablo, J. de 1999 [1621]. La extirpación de la idolotría en el Pirú. Edited by Henrique Urbano. Cuzco: Bartolomé de las Casas.

Bastien, Joseph W. 1978. Mountain of the condor: Metaphor and ritual in an Andean ayllu. American Ethnological Society Monograph 64. St. Paul: West.

Bauer, Brian S. 1998. The sacred landscape of the Inca: The Cusco ceque system. Austin: University of Texas Press.

Bauer, Brian S., and Charles Stanish. 1990. Killke and Killke-related pottery from Cuzco, Peru, in the Field Museum of Natural History. Fieldiania Anthropology n.s. 15.

Betanzos, Juan de. 1996 [1557]. Narrative of the Incas. Translated by Ronald Hamilton and Dana Buchanan. Austin: University of Texas Press.

Bird-David, Nurit. 1999. Animism revisited: Personhood, environment, and relational epistemology. Current Anthropoloogy 40:67-91.

Bolin, Inge. 1998. Rituals of respect: The secret of survival in the high Peruvian Andes. Austin: University of Texas Press.

Bray, Tamara. 2009. An archaeological perspective on the Andean concept of camaquen: Thinking through the objects of late pre-Columbian ofrendas and huacas. Cambridoe Archaeolooical Journal 19(3):359-68.

2014. The archaeology of wak'as: Explorations of the sacred in the pre-Columbian Andes. Boulder: University Press of Colorado

Cereceda, Verónica. 1986. "The semiology of Andean textiles: The talegas of Isluga," in Anthropological history of Andean polities. Edited by John V. Murra, Nathan Watchel, and Jacques Revel, pp. 149-74. Cambridge: Cambridge University Press.

—. 1987. "Aproximaciones a una estética Andina: de la belleza al tinku," in Tres reflexiones sobre el pensamiento Andino. Edited by Thèrése Bouysse-Cassagne, Olivia Harris, Tristan Platt, and Verónica Cereceda, pp. 133-231. La Paz: Hisbol.

Cieza de León, Pedro. 1967 [1553]. El señorío de los Incas (segunda parte de la Crónica del Perú). Lima: Instituto de Estudios Peruanos.

Cobo, Bernabe. 1990 [1653]. Inca religion and customs. Translated and edited by Roland Hamilton. Austin: University of Texas Press.

D’Altroy, Terence N. 2015. The Incas, second edition. Oxford: Blackwell.

de la Cadena, Marisol. 2014. Runa: Human, but not only. Lournal of Ethnographic Theory 4(2):253-59.

2015. Earth beings. Durham, NC: Duke University Press

Dean, Carolyn. 2010. A culture of stone: Inka perspectives on rock, Durham, NC: Duke University Press.

Descola, P. 1994. In the society of nature: A native ecology in Amazonia. Cambridge: Cambridge University Press. 
Dransart, Penelope Z. 1995. Elemental meanings: Symbolic expression in Inka miniature figurines. Research Paper 40. Institute of Latin American Studies, University of London.

2002. Earth, water, fleece and fabric: An ethnography and archaeology of Andean camelid herding. London: Routledge.

Fernández Juárez, Gerardo. 1997 Entre la repugnancia y la seducción: Ofrendas complejas en los Andes del Sur. Cuzco: CBC.

Flores-Ochoa, Jorge A. 1976. Enqa, enqaychu, illay y khuya rumi: Aspectos mágico-religiosos entre pastores. Journal of Latin American Lore 2(1):115-34.

- 1979. Pastoralists of the Andes. Translated by R. Bolton. Philadelphia: Institute for the Study of Human Issues.

- 1986. "The classification and naming of South American camelids," in Anthropological history of Andean polities. Edited by John V. Murra, Nathan Watchel, and Jacques Revel, pp. 137-48. Cambridge: Cambridge University Press.

Frazer, James G. 1915. The golden bough: A study in magic and religion, third edition. London: Macmillan.

Garcilaso de la Vega, el Inca. 1989 [1612]. Royal commentaries of the Incas and general history of Peru. Translated by Harold V. Livermore. Austin: University of Texas Press.

Glowacki, Mary. 2012."Shattered ceramics and offerings," in Wari: Lords of the ancient Andes. Edited by Susan Bergh, pp. 144-157. New York: Cleveland Museum of Art and Thames and Hudson.

Gose, Peter. 1986. Sacrifice and the commodity form in the Andes. Man 21:296-310.

1994. Deathly waters and hungry mountains: Agrarian ritual and class formation in an Andean town. Toronto: University of Toronto Press.

_. 2006. "Mountains historicized: Ancestors and landscape in the colonial Andes," in Kay Pacha: Cultivating earth and water in the Andes. Edited by Penny Dransart, pp. 2938. Oxford: British Archaeological Reports S1478.

Harvey, Graham. 2005. Animism: Respecting the living world. New York: Columbia University Press.

Hernández Príncipe, Rodrigo. 1923 [1621]. Mitología Andina. Edited by Carlos A. Romero. Inca 1:25-68.

Holguin, Diego G. 1989 [1608]. Vocabulario de la lengua general de todo el Peru, llamada lengua Quichua o del Inca. Lima: Universidad Nacional Mayor de San Marcos.

Hornborg, Alf. 2006. Animism, fetishism, and objectivism as strategies for knowing (or not knowing) the world. Ethnos 71(1):21-32.

Ingold, Tim. 2006. Rethinking the animate, re-animating thought. Ethnos 71(1):9-20.

Isbell, Billie Jean. 1985 [1978]. To defend ourselves: Ecology and ritual in an Andean village. Prospect Heights, IL: Waveland Press.

Lau, George. 2016. An archaeology of Ancash: Stones, ruins and communities in Andean Peru. London: Routledge.

Martinez, Gabriel. 1987. Una mesa ritual en Sucre: Aproximaciones semióticas al ritual Andino. La Paz: HISBOL.

Marett, R. R. 1914. The threshold of religion. London: Methuen.

Millones, Luis, 1989. Mesianismo e idolatría en los Andes Centrales. Lima: Biblos Editorial.

Mills, Kenith R. 1997. Idolatry and its enemies: Colonial Andean religion and extirpation, 1640-1750. Princeton: Princeton University Press. 
Paternosto, César. 1996. The stone and the thread: Andean roots of abstract art. Austin: Texas University Press

Pitrou, Perig. 2015. Life as a process of making in the Mixe Highlands (Oaxaca, Mexico): Towards a "general pragmatics" of life. Iournal of the Roval Anthropolooical Institute 21: 86-105.

Reinhard, Johan. 2005. The ice maiden: Inca mummies, mountain gods, and sacred sites in the Andes. Washington, DC: National Geographic Society,

Rodríguez Limache, Oscar C. 2009. Informe anual de componente de investigación arqeológica sector Qochapata P.A.S. Report submitted to the Instituto Nacional de Cultura, Cusco.

Rostworowski, María. 1986. Estructuras Andinas del poder: Ideología religiosa y politica. Lima: Instituto de Estudios Peruanos.

Shimada, Izumi, ed. 2015. The Inka Empire: A multidisciplinary approach. Austin: University of Texas Press

Sillar, Bill. 1996. Playing with God: Cultural perception of children, play and miniatures in the Andes. Archaeological Review from Cambridge 13(2):47-63.

- 2000. Shaping culture: Making pots and constructing households. An ethnoarchaeological study of pottery production, trade and use in the Andes. Oxford: British Archaeological Reports International Series 883.

- 2009. The social agency of things? Animism and materiality in the Andes. Cambridoe Archaeolooical Journal 19(3):367-77

-2013. Un patrimoine vivant: Les illas et conopas des foyers Andins—des objects irremplaçables. Techniques \& Culture 58:66-81.

Silverblatt, Irene. 1987. Moon, sun and witches: Gender ideologies and class in Inca and colonial Peru. Princeton: Princeton University Press.

Silverman, Gail P. 2008. A woven book of knowledge: Textile iconography of Cuzco, Peru. Salt Lake City: University of Utah Press

- 2012. The signs of empire: Inka writing. Cuzco: Editorial Kopygraf

Skar, Sarah L. 1994. Lives together-worlds apart: Quechua colonization in jungle and city. Oslo: Scandanavian University Press.

Stensrud, Astrid Bredholt. 2010. Los peregrinos urbanos en Qoyllurit'i y el juego mimético de miniaturas. Anthropologica 28:39-66.

Stobart, Henry. 2006. Music and the poetics of production in the Bolivian Andes. Aldershot: SOAS Musicology Series.

Stone-Miller, Rebecca. 1995. Art of the Andes: From Chavin to Inca. London: Thames and Hudson.

2006. "Mimesis as participation: Imagery, style, and function of the Michael C. Carlos Museum paccha, an Inka ritual watering device," in Kay Pacha: Cultivating earth and water in the Andes. Edited by Penny Dransart, pp. 215-24. Oxford: British Archaeological Reports S1478.

Taussig, Michael. 1993. Mimesis and alterity: A particular history of the senses. London: Routledge.

Tylor, Edward B. 1913. Primitive culture: Researches into the development of mythology, philosophy, religion, art, and custom. London: John Murray. (Originally published in 1871)

Viveiros de Castro, Eduardo. 1998. Cosmological deixis and Amerindian perspectivism. Lournal of the Roval Anthropological Institute 4:469-88. 
Weiner, Annette. 1992. Inalienable possessions: The paradox of keeping while giving. Berkeley: University of California Press.

Zedeño, Maria Nieves. 2008. Bundled worlds: The role and interactions of complex objects from the North American Plains. Iournal of Archaeolooical Method and Theory 15: $362-78$. 